\title{
DE்MESIO STOKOS IR HIPERAKTYVUMO SINDROMO RAIŠKOS MAŽINIMAS PAGAL TAIKOMOSIOS FIZINĖS VEIKLOS PROGRAMĄ
}

\author{
Giedrè Masiulioniené ${ }^{1}$, Jūratė Mikelkevičiūtè2, Vida Ostasevičienè ${ }^{2}$ \\ Kauno darželis-mokykla , Vaidilute "', Lietuvos kūno kultūros akademija², Kaunas, Lietuva
}

Giedrė Masiulionienė. Reabilitacijos magistrè. Kauno darželio-mokyklos „Vaidilutė“ kūno kultūros pedagogė. Mokslinių tyrimų kryptis — dėmesio stokos ir hiperaktyvumo sindromo (ADHD) ypatybių raiška ir jų pedagoginè korekcija per taikomają fizinę veiklą.

\section{SANTRAUKA}

Lietuvoje literatūros apie fizinio ugdymo programu taikyma vaikams, turintiems dèmesio stokos ir hiperaktyvumo sindroma (ADHD), rasti nepavyko. Tai paskatino imtis tyrimo, kurio tikslas - nustatyti taikomosios fizines veiklos programos poveiki ikimokyklinio amžiaus vaiku dèmesio stokos ir hiperaktyvumo sindromo ypatybiu pokyčiams. Buvo tiriama 10 (8 berniukai ir 2 mergaitès) Kauno darželio-mokyklos ,,Vaidilute “ ikimokyklinio (4 ir 5 m.) amžiaus vaiku, turinčiu dèmesio stokos ir hiperaktyvumo sutrikimu. Tyrimo metu naudoti šie metodai: 1) stebejjimas; 2) pedagoginis eksperimentas; 3) statistinè duomenu analize. Taikomosios fizinès veiklos programos turini sudaré smulkiosios motorikos pratimai, kartu vartojant ir kalbinę medžiaga (eilèraščius), taikyti ikimokyklinio amžiaus vaikams. Tyrimas truko 5 ménesius.

Auklètoju ir tèvu stebejjimu buvo registruojamas tiriamuju vaiku ADHD sindromo ypatybiu poreiškio dažnis (kartais) elgesyje triju skirtingu veiklu metu: ugdomosios protinès, ugdomosios fizinés ir lauko žaidimu metu. Stebimos ypatybés buvo suskirstytos $\dot{z} 3$ stambesnes grupes: 1) nesivaldymas; 2) per didelis aktyvumas; 3) dèmesio sukaupimo stoka.

Pagrindinès tyrimo išvados: 1. Auklètoju vertinimu, prieš ugdomaja programa labiausiai pasireiškè per didelis vaiku aktyvumas, po programos - vaiku ADHD sindromo tirtu ypatybiu poreiškis smarkiai sumažejo visu veiklų metu. Labiausiai sumažejo per didelis aktyvumas ugdomosios fizinès veiklos ir lauko žaidimu metu. 2. Tèvu vertinimu, prieš taikomosios fizines veiklos programq vyravo per didelis vaiku aktyvumas, o nesivaldymas ir demesio sukaupimo stoka pasireiške šiek tiek mažiau. Po taikomosios fizinès veiklos programos, tèvu nuomone, per didelis aktyvumas statistiškai reikšmingai sumažèjo. 3. Auklètoju ir tèvu stebejjimo duomenimis, vaiku dèmesio stokos ir hiperaktyvumo sindromo ypatybiu raiška po ugdomojo laikotarpio sumažejo, nors auklètojai kur kas geriau nei tévai ¿̨vertino taikomosios fizinès veiklos programos poveiki.

Raktažodžiai: dèmesio stokos ir hiperaktyvumo sindromas, taikomoji fizinè veikla.

\section{IVADAS}

$\mathrm{T}$ eigiama, kad net keturi milijonai vaiku ir nuo keturių iki penkių milijonų suaugusiujų JAV kenčia nuo dèmesio stokos ir hiperaktyvumo sindromo (ADHD). Gydytojai ADHD aprašè jau seniai, tačiau spartus jo plitimas pripažintas tik pastaruoju metu. Nors tiksliu duomenų nèra, tačiau manoma, kad nuo 3 iki 10 procentų mokyklinio amžiaus vaikų ir nuo 4 iki 5 procentų suaugusiujų turi ADHD. Dėmesio stokos ir hiperaktyvumo sindromas yra aktuali medicinos, mokymosi ir socialinè problema, kartu tai vienas iš dažniausiai pasitaikančiu psichikos sutrikimu

tarp vaiku (Cantwell, 1996; Wender, 2000). Šis sutrikimas gali pasireikšti labai anksti ir dažnai būna susijęs su mokymosi problemomis skaitant, rašant, skaičiuojant ir, beje, būdingesnis berniukams nei mergaitėms. Tokių vaikų veikla, reikalaujanti pažintinių gebejjimų, yra nepakankamai pastovi, jie linkę pereiti nuo vienos veiklos prie kitos, nè vienos iki galo nebaigdami; o pati veikla yra neorganizuota, neplaninga ir nekryptinga. Vaikai dažnai elgiasi neapgalvotai ir impulsyviai.

Vaiku psichiatrai mané, kad ADHD simptomai mažèja ir išnyksta vaikams augant, tačiau 
naujausi tyrimai parodè, kad jie dažnai išlieka ir paauglystėje, ir tarp suaugusiuju (Barkley, 1998; Wender, 2000). Pripažistama, kad ikimokyklinio ir jaunesniojo mokyklinio amžiaus vaikams labiau trūksta dèmesingumo, jie yra impulsyvesni ir hiperaktyvesni nei vyresnieji. Paprastai ADHD požymiai pastebimi įvairioje aplinkoje (namie, mokykloje, bendraujant su sau lygiais iki 7 metų amžiaus - APA, 2000). Negydant ir netaikant tikslingų edukacinių programų tikètina, kad ADHD turinčiam vaikui mokykloje vis daugès problemu, ir jis gali pradèti elgtis kaip rizikos grupès vaikas (Wender, 2000).

Tyrimo aktualumą lemia tai, kad Lietuvoje beveik kiekvienoje darželio grupejje, mokyklos klasėje yra vienas ar daugiau nedėmesingų, impulsyvių ar hiperaktyvių vaiku. Pastebèta, kad tokius vaikus sunkiau išmokyti: jie nereaguoja taip, kaip kiti vaikai, ir dažnai trukdo dirbti. Suprantama, kad vaikai, kuriems nustatytas dèmesio sutrikimaas ir hiperaktyvumas, kelia daug problemu ir tevams, ir pedagogams. Informacijos apie ši sindromą šiandien dar nepakanka. Be to, ji neretai prieštaringa (Sinkevičienè, 1998). H. Wender (2000) nurodo, kad daugeliu atveju gydymas vaistais gali sumažinti ar netgi pašalinti daugeli problemu ADHD vaikams, paaugliams ir suaugusiesiems, tačiau akcentuoja ne mažiau svarbią ir efektyvią kryptingos edukacinès programos (specialiosios edukacijos) reikšmę.

Viena iš edukacinès programos priemonių, padedančiu ADHD vaikams mažinti jo poreiški, galètų būti taikomoji fizinè veikla. W. J. Harvey ir G. Reid (2003) teigia, kad nuo 1949 iki 2002 metu buvo atlikti 49 empiriniai tyrimai, nagrinèjantys ADHD vaikų motorinę elgseną. Autoriai teigia, kad yra mažai informacijos apie fizinès veiklos programų taikymą ši sutrikimą turintiems vaikams. Tik keletas mokslininku nagrinejo tokių vaikų fizinę veiklą (Churton, 1989), judesiu atlikimą ir fizini pajègumą (Stubbe, 2000 b), keli autoriai tyrè šiu vaiku fizinio ugdymo problemas (Bishop \& Beyer, 1995; Sherill, 1998; Craft, 2000). W. J. Harvey ir G. Reid (2003) pažymi, kad mokslininkams, dirbantiems su ADHD vaikais taikomosios fizinès veiklos srityje, yra daug neaiškių klausimų. Lietuvoje literatūros apie fizinio ugdymo programų taikymą tokiems vaikams rasti nepavyko. Tai paskatino mus imtis tyrimo ir kelti tokią hipotezę: kryptinga taikomoji fizinè veikla mažina dèmesio stokos ir hiperaktyvumo sindromo poreiškị.
Tyrimo objektu pasirinkome vaikų dėmesio stokos ir hiperaktyvumo sindromo ypatybiu raišką skirtingu veiklu metu (ugdomosios protinès, ugdomosios fizinès ir lauko žaidimų metu). Tyrimo tikslas - nustatyti taikomosios fizinès veiklos programos poveiki ikimokyklinio amžiaus vaiku dèmesio stokos ir hiperaktyvumo sindromo ypatybiu pokyčiams.

\section{TYRIMO ORGANIZAVIMAS IR METODAI}

Buvo tiriama 10 ( 8 berniukai ir 2 mergaitès) Kauno darželio-mokyklos „Vaidilute“ ikimokyklinio (4 ir $5 \mathrm{~m}$.) amžiaus vaikų, turinčių demesio stokos ir hiperaktyvumo sutrikimų. Šis amžiaus tarpsnis pasirinktas remiantis mokslininkų (Taylor et al., 1998; Wender, 2000) rekomendacijomis, nurodančiomis ADHD atpažinimo ir kryptingo ugdymo svarbą dèl dviejų priežasčių. Pirma, ugdymas padeda vaikui dabar. Jei vaikas mokosi lengviau, tai padeda jam išvengti nerimo bei depresijos, susijusių su akademiniais sunkumais, nepopuliarumo tarp kitų vaikų ir konfliktų su tèvais. Antra, ankstyvas ugdymas gali sumažinti problemiško elgesio riziką, kuri, tikètina, ADHD turinčiam vaikui išsivystys paauglysteje.

Daugelis mokslininkų, atliekančių neigaliujų tyrimus socialinių mokslų srityje, teigia, kad net ir pačioje neigaliuju grupeje egzistuoja individualūs pakenkimo ir negalios skirtumai, todèl ne visada galima naudotis patikimos atrankos ir imties sudarymo principais (Shephard, 1999). Anot B. Bitino (1998), edukologinių tyrimų metu gali būti taikoma ne tik statistinè, bet ir kokybinè imtis, kuri sudaroma atsižvelgiant $\mathfrak{i}$ tikslus ir turini. Todèl tiriamuosius pasirinkome tiksliniu būdu pagal tokius kriterijus: nustatytas ADHD; gyvena su abiem tèvais; lanko Kauno darželi-mokyklą „Vaidilute“. Tiriamujų ADHD diagnozavo pedagoginès psichologinès tarnybos specialistai, remdamiesi tikslingu pokalbiu su tèvais, vaiku ir auklètojais.

Tyrimas buvo atliekamas $2005 \mathrm{~m}$. rugsejjogruodžio mėnesiais, eiga ir organizavimas suderintas su darželio-mokyklos vadovybe ir tiriamuju tèvais. Tyrimo metu, norint sumažinti vaikų dèmesio stokos ir hiperaktyvumo sindromo požymius, pagal G. Musteikienès (2001) praktines rekomendacijas buvo parengta ir taikyta fizinès veiklos programa, skirta lavinti ADHD vaiku smulkiaja motoriką. Ikimokyklinio amžiaus vaikai turejjo 
1 lentelè. ADHD sindromo ypatybių poreiškio skirtingų veiklų metu rezultatų vidurkiai (M $\pm \mathbf{m})$

\begin{tabular}{|c|c|c|c|c|c|c|c|c|c|}
\hline \multirow{2}{*}{ Ypatybès } & \multicolumn{2}{|c|}{$\begin{array}{l}\text { Ugdomosios veiklos } \\
\text { metu }\end{array}$} & \multirow{2}{*}{$\begin{array}{c}\mathrm{p} \text { tarp } \\
\text { ypatybių }\end{array}$} & \multicolumn{2}{|c|}{ Fizinės veiklos metu } & \multirow{2}{*}{$\begin{array}{c}\mathrm{p} \text { tarp } \\
\text { ypatybių }\end{array}$} & \multicolumn{2}{|c|}{ Lauko žaidimų metu } & \multirow{2}{*}{$\begin{array}{c}\mathrm{p} \text { tarp } \\
\text { ypatybiu }\end{array}$} \\
\hline & prieš & po & & prieš & po & & prieš & po & \\
\hline Nesivaldymas & $3 \pm 0,99$ & $1,8 \pm 0,53$ & $\mathrm{p}=0,044^{*}$ & $3,8 \pm 0,93$ & $2,5 \pm 0,78$ & $\mathrm{p}=0,018^{*}$ & $5,8 \pm 0,66$ & $3,8 \pm 0,53$ & $\mathrm{p}=0,000 * * *$ \\
\hline Aktyvumas & $6,5 \pm 0,455$ & $4,9 \pm 0,46$ & $\mathrm{p}=0,016^{*}$ & $7,8 \pm 0,66$ & $5,3 \pm 0,45$ & $\mathrm{p}=0,000 * * *$ & $6,9 \pm 0,53$ & $4,4 \pm 0,48$ & $\mathrm{p}=0,002 * *$ \\
\hline $\begin{array}{l}\text { Dèmesio } \\
\text { sukaupimas }\end{array}$ & $6,5 \pm 0,64$ & $4,3 \pm 0,47$ & $\mathrm{p}=0,001 * *$ & $4 \pm 0,58$ & $3,1 \pm 0,46$ & $\mathrm{p}=0,004 * *$ & $3,8 \pm 0,72$ & $2,6 \pm 0,58$ & $\mathrm{p}=0,005 * *$ \\
\hline
\end{tabular}

Pastaba. * $-\mathrm{p}<0,05 ; * *-\mathrm{p}<0,01 ; * * *-\mathrm{p}<0,001$.

atlikti pratimus ranku pirštams mankštinti, kartu buvo vartojama ir kalbinè medžiaga (eilèraščiai). Pratybos vykdavo tris kartus per savaitę, 1 karta per dieną po 8 minutes $(5-8$ minučiu per dieną pakanka, kad būtų skatinama galvos smegenų žievès motorinè veikla) (Musteikienè, 2001).

Stebejimo metodu, remiantis H. Wender (2000) stebejimo protokolų sudarymo rekomendacijomis, protokoluose buvo registruojamas tiriamuju ADHD sindromo ypatybiu poreiškis ugdomosios protinès ir ugdomosios fizinès veiklos (organizuota fizinè ugdomoji veikla turèjo tikslą, uždavinius, tam tikrą metodiką ir truko apibrèžtą laiką) ir lauko žaidimų metu (laisva veikla lauke).

Stebimos ypatybès buvo suskirstytos i 3 stambesnes grupes: 1) nesivaldymas (tai muštynès, agresyvūs veiksmai, impulsyvumas, keiksmažodžiai); 2) per didelis aktyvumas (judesys atliekamas per daug intensyviai esant tam tikrai situacijai; atskiri judesiai atliekami dar nesant situacijos; sunkiai nusèdima diskusijos apie būsimą veiklą metu); 3) dèmesio sukaupimo stoka (kai nesekama judesio situacija; atrodo paskendęs savo mintyse; negeba nuolatos atlikti judesiu situacijos metu; greitai išsiblaško dèl pašalinių situacijos priemonių arba tiesiog kalbina kitus veiklos, aiškinimu metu).

Ugdymo įstaigoje stebejjimo protokolus pildè auklètojos, o tų pačiu ypatybiu poreiški namie fiksavo tèvai. Stebejjimas vyko vieną mènesi, kas antrą savaitę kiekvienos veiklos metu prieš tyrimą ir po jo. Buvo išanalizuota 60 auklètojų ir 10 tiriamuju tėvų užpildytu protokolų prieš tyrimą ir tiek pat po jo (iš viso 140 protokolu).

Statistinė duomenų analizė atlikta naudojant duomenu kaupimo ir analizès SPSS 13 for Windows programos paketą. Tiriamuju grupių nagrinėjami požymiai aprašyti naudojant bendrosios statistikos padèties, išsibarstymo ir simetrijos apibūdinimus. Kiekybiniai dydžiai palyginti naudojant Stjudento t kriterijų, taikomą priklausomoms imtims. Kadangi imtis nedidelè $(\mathrm{n}=10)$, skirtu- mui tarp dviejų nepriklausomų grupių duomenų nustatyti atliktas ir neparametrinis Mann-Whitney (U) testas.

\section{REZULTATAI}

Išanalizavus auklètojų stebejjimo duomenis apie ADHD sindromo ypatybių poreiškio dažnumą prieš eksperimentą visų veiklu metu atskirai paaiškejjo, kad labiausiai pasireiškè per didelis aktyvumas, kuris didžiausias buvo ugdomosios fizinès veiklos metu $(7,8 \pm 0,66)$. Dèmesio sukaupimo stoka ir per didelis aktyvumas pastebetas ir ugdomosios protinès veiklos metu $(6,5 \pm 0,64$ ir $6,5 \pm 0,45)$. Žaidžiant lauko žaidimus, taip pat kaip ir fizinès ugdomosios veiklos metu, dominavo per didelis aktyvumas $(6,9 \pm 0,53)$ (1 lent.). Palyginus auklètojų stebejjimo duomenis lauko žaidimų metu prieš tyrimą ir po jo pastebèta, kad po taikomosios fizinès veiklos programos dèmesio stokos ir hiperaktyvumo simptomams mažinti reikšmingai sumažèjo vaikų aktyvumas (nuo $6,9 \pm 0,53$ iki $4,4 \pm 0,48 ; p<0,01)$, nesivaldymo ypatybių poreiškis (nuo 5,8 $\pm 0,66$ iki $3,8 \pm 0,53$; $\mathrm{p}<0,001$ ) (1 lent.). Démesio sukaupimo stoka prieš tyrimą lauko žaidimų metu buvo mažiausiai išreikšta lyginant su kitomis stebètomis ypatybèmis, tačiau po ugdomosios programos jų raiška taip pat reikšmingai sumažejo (nuo 3,8 $\pm 0,72$ iki $2,6 \pm 0,58$ kartu; $\mathrm{p}<0,01)$. Ugdomosios protinès veiklos metu mažiausiai pasireiškè nesivaldymas $(3 \pm 0,99)$. Kryptingai taikyta ugdomoji programa padejjo sumažinti labiau išreikštas per didelio aktyvumo ir demesio sukaupimo stokos ypatybes (nuo 6,5 $\pm 0,45$ iki 4,9 $\pm 0,46(\mathrm{p}<0,01)$ ir nuo $6,5 \pm 0,64$ iki 4,3 $\pm 0,47(p<0,001))$. Nagrinėjant auklètojų stebejjimo rezultatus ugdomosios fizinès veiklos metu prieš tyrimą ir po jo paaiškejjo, kad dèl taikomosios fizinès veiklos programos poveikio per didelis aktyvumas statistiškai reikšmingai sumažèjo (nuo 7,8 $\pm 0,66$ iki 5,3 $\pm 0,45$; $\mathrm{p}<0,001)$. Mažiausiai ugdomosios fizinès veiklos 


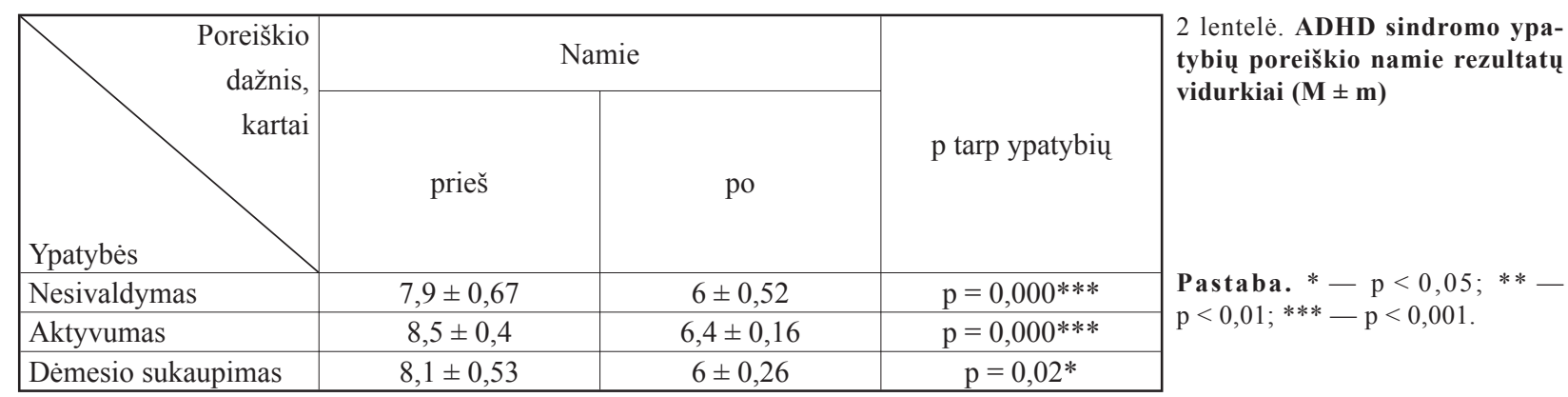

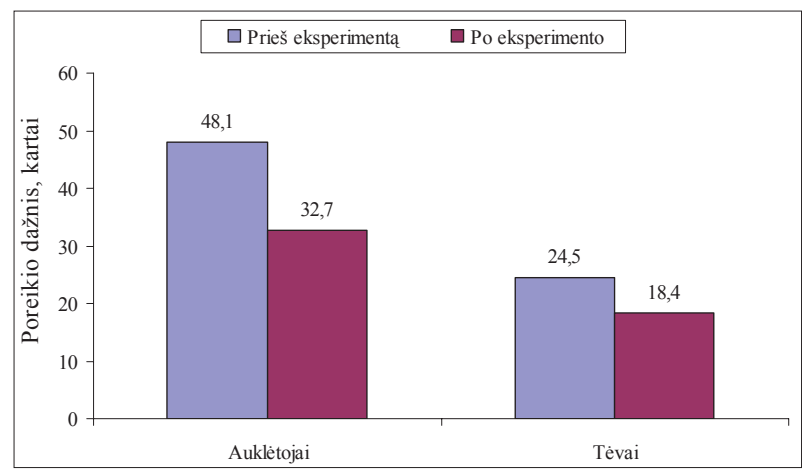

Pav. Tẻvų ir auklètojų stebėjimo rezultatų palyginimas vertinant vaikų ADHD ypatybių raišką prieš tyrimą ir po jo

metu kito dèmesio sukaupimo stoka $(4 \pm 0,58$ ir $3,1 \pm 0,46)$ (1 lent.).

Apibendrinus ADHD sindromo ypatybių raiškos auklètojų stebejjimo duomenis visų veiklų metu galima pastebèti, kad prieš tyrimą nesivaldymo, per didelio aktyvumo, dèmesio sukaupimo stokos atveju buvo daugiau nei po tyrimo $(48,1 \pm 3,0$ ir $32,7 \pm 2,12 ; p<0,001)$ (žr. pav.).

Visos tiriamų vaikų elgesio ypatybès, tèvų stebejjimo duomenimis, labiau pasireiškè prieš tyrimą nei po jo. Stebejjimo protokolu analize parodè, kad tèvai labiausiai pastebejo per dideli vaikų aktyvumą $(8,5 \pm 0,4)$, šiek tiek mažiau dèmesio sukaupimo stokos $(8,1 \pm 0,53)$ ir mažiausiai nesivaldymo $(7,9 \pm 0,67)$ požymių. Po kryptingos programos šių ypatybių raiškos atvejų akivaizdžiai sumažejo $(\mathrm{p}<0,001)(2$ lent. $)$.

Palyginus auklètojų ir tèvų ADHD sindromo ypatybių poreiškio vidurkius prieš tyrimą pastebèta, kad auklètojai jų užfiksavo daugiau nei tẻvai $(48,1 \pm 3,0$ ir $24,5 \pm 1,16)$ (žr. pav.). Po tyrimo ir auklètojos $(32,7 \pm 2,12)$, ir tèvai $(18,4 \pm 0,64)$ pastebejo tirtu ADHD sindromo ypatybių raiškos mažèjimą vaikų elgesyje (žr. pav.).

\section{REZULTATŲ APTARIMAS}

Apibūdinti vaikus, turinčius dėmesio stokos bei hiperaktyvumo sindromo ypatybių, kai kuriais aspektais yra sudetinga. ADHD vaikus charakterizuoti gali simptomu stiprumas, nuolatinis ju po- reiškis ir modeliavimas (grupės simbolių buvimas) (APA, 2000). Pasak A. Ališausko (1996), dèmesio stokos ir hiperaktyvumo sindromas pasireiškia nedèmesingumu (vaikas lengvai išsiblaško, nustoja dirbęs dèl menkiausio triukšmo, ilgesnị laiką negali tą pati darbą dirbti susikaupęs, vaiko dèmesi vienu metu patraukia keli skirtingi dalykai, ypač sunkiai jis paskirsto demesi ir pan.), impulsyvumu (puola dirbti neišsiaiškinęs, ką ir kaip reikia daryti; jei nori ką papasakoti, negali susilaikyti, sulaukti savo eilès ir pan.) ir perdètu motoriniu aktyvumu (ilgesni laiką ramiai nenusèdi, nuolat stojasi iš vietos, žaidimo metu aktyvesnis už kitus ir pan.). R. E. Reeve (1990) pažymi, kad atsitraukimas nuo ugdomosios veiklos nebūtinai turi pasireikšti visuomet. Dažnai, kai vaikas jaučia asmenini dèmesi, jis kurị laiką gali laikytis puikiai. Mokytojas gali pranešti, kad jam ,gerai sekasi, kai jaučia individualų dèmesį“. Psichologas gali pažymèti, kad vaikas geba atkreipti dèmesi testavimo metu. Pediatras gali pastebèti, kad vaikas buvo dèmesingas jo trumpo kabinetinio stebejjimo metu. Jie visi teisūs, tačiau daugelis ADHD vaikų gali atidžiai klausytis tik trumpą laiką. Jei tyrèjas, vaiku psichiatras, pediatras ar psichologas nesuvokia tokio elgesio kaitos, jis (ji) gali padaryti netikslią išvadą teigdamas, kad vaikui viskas gerai ir kad jo tevai, mokytojas reaguoja per jautriai (Wender, 2000). Todèl vertinant vaiko elgesi labai svarbi tèvų, pedagogų ir kitų vaiko aplinkos asmenų informacija. H. Wender (2000) tyrimais nustate, $\operatorname{kad} 76 \%$ darželinukų tèvų manè, kad jų vaikai kur kas aktyvesni, negu buvo iš tikrujų. Tuo tarpu pedagogai informacijos apie vaiką turi daugiau, nes kiekvieną dieną dirba su juo. Tai patvirtina ir mūsų tyrimo rezultatai - auklètojų vertinimas buvo reikšmingai blogesnis nei tėvų. Viena tokio skirtumo prielaidų galètų būti ta, kad auklètojos kur kas daugiau laiko praleidžia su vaikais, mato jų elgesi ịvairių veiklų metu, vertina socialinès kompetencijos igūdžius. Tikètina, kad jų vertinimas daugiau objektyvus nei subjektyvus, o tèvai savo vaikus vertina labai subjektyviai. 
Auklètojų stebėjimo duomenimis, visų veiklų metu labiausiai pasireiškè per didelis aktyvumas. Nors šios ypatybės raiška po taikomosios fizinès veiklos programos sumažèjo, tačiau ji išliko vyraujanti. Tai patvirtina ir D. P. Cantwell (1996) tyrimai, kuriais teigiama, kad daugelis ADHD vaiku yra pernelyg aktyvūs nuo ankstyvos kūdikystès. Atlikto tyrimo duomenimis, ugdomosios protinès veiklos metu mažiausiai pasireiškè nesivaldymas (impulsyvumas). Šiuos rezultatus galima paaiškinti D. E. Stubbe (2000 a) teiginiu, kad ADHD turintis vaikas elgiasi pagal momentini impulsą. Mūsų tyrimo rezultatai parode, kad skirtingų veiklų metu nevienodai pasireiškè ir vaikų dėmesio stoka bei elgesio ypatybès. Galima kelti prielaida, kad itakos vaikui turejo skirtinga aplinka ir tam tikros veiklos apibrèžtumas.

Apibendrinus tėvų ir auklètojų stebejimo rezultatus prieš tyrimą ir po jo, pastebèti akivaizdūs vertinimo pokyčiai. Prieš taikomosios fizinès veiklos programą tiriamuju vaikų elgesio ypatybès (nesivaldymas, per didelis aktyvumas ir demesio sukaupimo stoka) visų stebètų veiklų metu buvo kur kas labiau išreikštos nei po eksperimento. Tokius teigiamus pokyčius galima paaiškinti šitaip: smulkiosios motorikos lavinimas, kartu taikant ir kalbines pratybas, teigiamai veikè galvos smegenu žievès kaktos skilties funkcijas, kurios, kaip manoma, reguliuoja dèmesio stokos ir hiperaktyvumo poreiški (Daulenskienè, 1987). Be to, vaikų rankų smulkiosios motorikos lavinimo užduotys padeda susikaupti, išlaikyti dèmesî, lavina atmintị, mąstymą (Musteikienè, 2001).
Atlikto tyrimo rezultatai patvirtino hipotezę, kad kryptinga ugdomoji fizinè veikla mažina ADHD sindromo ypatybių raišką. Visgi reikalinga išsamesnè mokslinė studija, kuri ne tik praktiškai, bet teoriškai pagrịstu ADHD sindromo ypatybių raiškos pokyčius dèl taikomosios fizinès veiklos programu poveikio ankstyvuoju ir kitais amžiaus tarpsniais. Kita vertus, atliktas tyrimas galètu skatinti mokslininkus išsamiau paanalizuoti asmenų, turinčių ADHD, ir jų šeimų sveikatą ir gyvenimo kokybę.

\section{IŠVADOS}

1. Auklètojų vertinimu, prieš tyrimą labiausiai pasireiškè per didelis vaikų aktyvumas, po taikomosios fizinès veiklos programos - ADHD vaikų tirtų ypatybių poreiškis smarkiai sumažejo visų veiklų metu. Labiausiai sumažejo per didelis aktyvumas ugdomosios fizinès veiklos ir lauko žaidimų metu.

2. Tẻvų vertinimu, prieš tyrimą vyravo per didelis aktyvumas, o nesivaldymas ir demesio sukaupimo stoka pasireiškè šiek tiek mažiau. Po taikomosios fizinès veiklos programos per didelis aktyvumas statistiškai reikšmingai sumažèjo.

3. Auklètojų ir tėvų stebejjimo duomenimis, vaikų dèmesio stokos ir hiperaktyvumo sindromo ypatybių raiška po tyrimo sumažejo, nors auklètojai kur kas geriau nei tèvai ịvertino taikomosios fizinès veiklos programos poveiki.

\section{LITERATŪRA}

Ališauskas, A. (1996). Vaiku vystymosi ypatingumu pažinimas ir ivertinimas. Šiauliai: Šiaulių pedagoginis universitetas.

APA (American Psychiatric Association). (2000). Diagnostic and Statistical Manual of Mental Disorders (4 th ed.). Text Revision. Washington.

Barkley, R. A. (1998). Attention-Deficit Hyperactivity Disorder: A Handbook for Diagnosis and Treatment. New York: Guilford Press.

Bishop, P. \& Beyer, R. (1995). Attention deficit hyperactivity disorder (ADHD): Implications for physical educators. Palaestra, 11 (4), 39-45.

Bitinas, B. (1998). Ugdymo tyrimu metodologija. Vilnius: Jošara.

Cantwell, D. P. (1996). Attention deficit disorder: A review of the past 10 years. Journal of the American Academy of Children and Adolescent Psychiatry, 35, 978-987.

Churton, M. W. (1989). Hyperkinesis: A review of the literature. Adapted Physical Activity Quaterly, 6, 313-327.
Craft, D. H. (2000). Learning disabilities and attention deficits. In J. P. Winnick (Ed.), Adapted Physical Education and Sport (3 ed.; pp. 127-141). Champaign, IL: Human Kinetics.

Daulenskienè, J. (1987). Medicininiai kompleksiniai korekcijos pagrindai pagalbineje mokykloje. Vilnius.

Harvey, W. J., Reid, G. (2003). Attention-deficit / Hyperactivity disorder: A review of research on movement skill performance and physical fitness. Adapted Physical Activity Quarterly, 22, 1-20.

Musteikiene, G. (2001). Žaidimai ranku pirštams lavinti. Šiauliai.

Reeve, R. E. (1990). ADHD: Facts and fallacies. Intervention in School and Clinic, 26, 70-78.

Shephard, R. J. (1999). Postmodernism and adapted physical activity: A new gnostic heresy? Adapted Physical Activity Quarterly, 16, 331-343.

Sherill, C. (1998). Adapted Physical Activity, Recreation and Sport: Crossdisciplinary and Lifespan. Dubuque, IA: WCB / McGraw-Hill. 
Sinkevičienè, D. (1998). Sudètinga vaikystè: straipsniu rinkinys. Vilnius: Lietuvos pedagogu kvalifikacijos centras. P. $15-26$.

Stubbe, D. E. (2000 a). Attention deficit / hyperactivity disorder: Historical perspective, current controversies, and future direction. Child and Adolescent Psychiatric Clinic of North America, 9, 469-479.
Stubbe, D. E. (2000 b). Preface. Child and Adolescent Psychiatric Clinics of North America, 9, xiii-xvii.

Taylor, E., Sergeant, J., Doepfner, M. et al. (1998). Clinical guidelines for hyperkinetic disorder. Europian Child \& Adolescent Psychiatry, 7, 184-200.

Wender, H. (2000). Attention - Deficit / Hyperactivity Disorder in Children, Adolescents, and Adults. New York: OXFORD.

\title{
DECREASE OF THE MANIFESTATION OF ATTENTION DEFICIENCY AND HYPERACTIVITY SYNDROME IN PRE-SCHOOL AGE CHILDREN AFTER APPLYING THE PROGRAM OF APPLIED PHYSICAL ACTIVITY
}

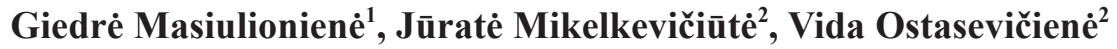 \\ „,Vaidilute்" Pre-school', Lithuanian Academy of Physical Education", Kaunas, Lithuania
}

\begin{abstract}
The article analyses the manifestation of pre-school age children's attention deficiency and hyperactivity (ADHD) and their alterations due to the impact of adapted physical activity program. No research was found on the impact of the program of physical education for children with ADHD. The aim of the study was to determine the impact of adapted physical activity on the changes in the characteristics of ADHD. 10 (8 boys and 2 girls) pre-school age children (aged 4 and 5 years) with attention deficiency and hyperactivity syndrome, educated at Vaidilute pre-school in Kaunas took part in the research. Three research methods were used: 1 . The application of the adapted physical activity program; 2. Observation; 3. Statistical data analysis. Research applied the adapted physical activity program, which consisted of games to train manipulative motor skills together with language activities (poems) for pre-school age children. The study lasted for 5 months.

The observation allowed registereing expressions of the characteristics of ADHD syndrome in tree different areas: mental activities, educational physical activities and outdoor activities. Observa ed features were classified into tree groups: 1) impulsivity; 2) hyperactivity; 3 ) attention deficiency.

The main conclusions: 1 . According to the teachers' observation, hyperactivity was expressed most before the experimental program. After the educational period, after the application of the adapted physical activity program, the manifestation of all the characteristics of attention deficiency and hyperactivity syndrome decreased. Hyperactivity decreased most of all during targeted physical activities and outdoor games. 2 . The parents' evaluation showed that hyperactivity was a dominating feature, but attention deficiency and lack of restraint were expressed less compared to hyperactivity. Assessment by parents demonstrated decreasing hyperactivity after the program was applied. 3 . The research showed that adapted physical activity program had a positive effect on the changes in ADHD characteristics, but teachers were more positive in evaluation of targeted adapted physical activity compared to parents.
\end{abstract}

Keywords: attention deficiency and hyperactivity syndrome (ADHD), adapted physical activity.

Gauta 2006 m. rugsejjo $11 \mathrm{~d}$.

Received on September 11, 2006

Priimta $2007 \mathrm{~m}$. vasario $13 \mathrm{~d}$.

Accepted on February 13, 2007
Vida Ostasevičienė

Lietuvos kūno kultūros akademija

(Lithuanian Academy of Physical Education)

Sporto g. 6, LT-44221 Kaunas

Lietuva (Lithuania)

Tel +370 37302660

E-mail v.ostaseviciene@1kka.1t 